\title{
THE IMPLICATIONS OF THE
REGULATIONS FOR
THE UNIVERSITIES
} BARBARA ROBERTSON

\section{INTRODUCTION}

The inclusion of nursing education into the tertiary education system of the country is indeed a milestone in the development of the nursing profession. Nursing education has now been recognised by the country and it is up to all of us to ensure that nurses educated through this new system are competent and can provide quality service to the health consumer.

In looking at the implications of the new course for the university one could say that the overall function of the university is to be the guardian of the academic standards of the colleges that are associated with it.

Let us now look at this in greater detail under three main headings, namely

- planning for the implementation of the new curriculum

- the continuing role of the university

- financial aspects.

In this discussion cognisance has been taken of relevant aspects in the guidelines drawn up for cooperation between universities and colleges by the Department of National Education.

\section{PLANNING \\ Pre-requisites}

This stage can only commence after the principal of a particular university has received a request from the authority under which the college resorts requesting the college to be associated with it. This request implies that:

- the requesting authority ap-

Prof. B. Robertson, D Litt et Phil

(Unisa), RN, RM, Community

Nurse, Tutor, Nursing Adminis-

tration. Professor. Department of

Nursing Science, University of South

Africa.

\section{OPSOMMING}

Die oorhoofse funksie van die universiteit in 'n samewerkingsooreenkoms met 'n kollege van verpleging is om oor die akademiese standaarde van die kollege toesig te hou.

Nadat 'n universiteit ingestem het tot 'n versoek van 'n owerheid om met 'n spesifieke kollege saam te werk word 'n ooreenkoms aangegaan. Hierdie ooreenkoms moet voorsiening maak vir die samestelling en funksies van die kollegeraad, en die kollegesenaat waarop. onder andere, verteenwoordigers van die Universiteit dien.

Universiteitspersoneel maak ook 'n inset in die kurrikulum en die Universiteit moet dit goedkeur. Hulle sal die kollegefasiliteite inspekteer om te verseker dat dit geskik is vir die opleiding van waardige verpleegpraktisyns. Die universiteit is ook daarvoor verantwoordelik om alle eksamens te modereer. Kortom, die universiteitspersoneel verseker dat die universiteit daarin geregverdig is om die kollegediploma te endosseer.

proves the association

- the college is autonomous and is directly responsible to its controlling authority which in the Transvaal would be the Transvaal Provincial Department of Hospital Services

- there will be some sort of enabling legislation, such as an act, ordinance or regulation empowering the college with the responsibility for the education and training of nurses. The type of legislation obviously depends on the authority controlling the college, that is the state, province or private body.

The university may then set up a committee of senior staff which will include the head of the department of nursing science, and this body will give the nursing department permission to commence with the planning phase.

\section{Document of agreement}

The committee will liaise with the controlling authority on the drawing up of a document of agreement between them. For a provincial college the agreement would be between the university and the relevant provincial administration. The agreement makes provision for cooperation between the two authori- ties through two governing bodies, namely the college council and the senate. In drawing up this document of agreement the university must ensure that the aspects discussed below are included.

\section{The College Council}

\section{Composition}

The College Council should consist of members

- nominated by the administrator (one of whom must be the chief matron of the main hospital where facilities for learning experiences will be provided)

- representatives of the university, one of whom should be the head of the nursing department

- members nominated by the college senate who are members of the college senate and staff

- a representative of the Department of Health and Welfare.

The chairman could be chosen by the administrator in consultation with the university. The college principal is vice-chairman.

\section{The powers and functions}

The powers and functions of the college council are as follows:

- advising the director on the training requirements and physical facilities required 
- dealing with disciplinary matters relating to students and reported to it by the head of the college and all disciplinary matters relating to staff before they are sent to the relevant controlling authority

- making recommendations for the appointment of staff provided that they meet the criteria set for the appointment of lecturers by the university and the college. The final appointment rests again with the controlling authority

- controlling the number of students that has been agreed upon

- dealing with all matters referred to it by the college senate relating to courses, syllabi, research, examinations, promotion of students and personnel matters

- submitting a budget through the college principal to the controlling authority. The university senate must first have been consulted on any matters related to the provision of clinical and academic facilities establishing subcommittees from time to time to give attention to such matters as deemed necessary by the Council.

\section{The College Senate}

The college senate functions under the college council and carries out those duties assigned to it by the council.

\section{Composition}

This body should be composed of

- members of the college staff (who should be in the majority)

- a representative of the controlling department nominated by the director

- representatives of the university department of nursing science

- a representative from the main hospital supplying facilities for learning experiences.

The college principal should be chairman and the vice-principal should be vice-chairman

\section{Power and functions}

The powers and functions of the senate should include:

- the exercise of control over the curriculum, examinations, credits for courses passed, requirements for the awarding of the diploma and other matters assigned to it by the university senate and college council
- the making of recommendations to the council on staff requirements and academic planning

- the establishment of sub-committees from among its own staff as required

- the control of college publications

- the draft budget

- the promotion of research.

The senate, together with its executive committee consisting of the principal, vice-principal and one other college staff member of the senate, is the working body. The executive committee handles day to day problems.

\section{General matters}

General matters that should be included in such a document of agreement, are

- the number of members of each body that form a quorum

- the term of office of members

- the frequency of meetings

- details of special meetings

- secretaryship of meetings

- the clear spelling out on whose establishment staff belong

- mutual agreement on the use of college and university facilities

- position of students. It must be made clear that the students do not belong to the university

- the conducting of examinations by the college and their moderation by the university

- endorsement of the diplomas by the university

- the acceptance of costs incurred by the university staff by the authority under which the college resorts.

\section{Macro-planning of the curriculum}

The members of the nursing department of the university will assist the curriculum committee of the college to draw up the broad objectives and curriculum for the new course. This curriculum must fit university requirements and will be prepared by the nursing departments for submission to the faculty board and senate of the university.

\section{Aspects that will be considered}

- Requirements for admission to the course. These include the number of intakes per year, the minimal educational requirements, registration as a student with the South African Nursing Council and the SA Nursing Association. The College may set other entrance criteria.

- Duration of the course. The course must extend over at least four academic years.

- The curriculum. This must fit in with any requirements laid down by the university, e.g. a semester system, as well as the minimum requirements of the SA Nursing Council. It is the responsibility of the university to control the academic standards set by the college. If more than one college is affiliated to a university the university may require them to follow the same broad curriculum. This does not preclude individual emphasis being placed on course content according to the nursing needs of an area. The key word in all the planning is flexibility

The following is an example of the division of subjects in a curriculum:

- General Nursing Science and Art I II III IV

- Community Health Nursing Science I II III IV

- Midwifery I II III

- Psychiatric Nursing I II

- Sociology I II

- Scientific Foundation of Nursing I II III

- Ethos of Nursing and Professional Practice I

- Comprehensive Nursing and Midwifery Practice I II III IV

\section{Credits}

Where possible students should be given credits for courses done at the college on the basis of one credit for two college courses should they wish to do graduate studies at the university with which the college is associated. These credits only apply to courses offered at the specific university.

In the example provided above the student could be given credits for Sociology I and Community Health I and II. This arrangement needs to be discussed within the nursing department and other relevant departments, such as the Department of Sociology. The nature 
and extent of the content of the two courses must cover the content of the course for which a credit is obtained. Such credits are not necessarily given by other universities.

\section{Examinations}

Agreement must be reached on the semester or year mark required for examination entry, the percentage required to pass and also the percentage needed for a distinction. Provision must be made for supplementary examinations and for special examinations in cases of illness and other extenuating circumstances. The university will also give guidance on the subjects that must be passed in order to proceed to the next year of study and in how many courses a student may do a supplementary examination.

\section{Concurrent formal clinical learning opportunities}

These are spread over four years and the university staff must concur on which facilities will be used and which aspects can be done through simulation or laboratory work.

The staff will assist in drawing up a document in similar format to that found in a university calendar. This is submitted for approval by the faculty board and the senate of the university. They will also approve the document that is submitted by the college to the SA Nursing Council.

\section{Inspection of the facilities}

The university staff have to satisfy themselves that

- the physical facilities for teaching, audio-visual material, library facilities, administrative facilities, teaching establishment and student support systems at the college are adequate

\section{and}

- that the clinical learning opportunities provided for general nursing, midwifery, psychiatric nursing and community health nursing are adequate to enable the student to learn to be a competent nurse practitioner.

Prior to the commencement of the course the university nursing staff will need to spend time with the college staff and those in clinical practice evaluating the quantity and quality of learning opportunities that can be provided. In some instances it may be necessary for special arrangements to be made for students to get some aspects of their education at institutions far removed from their college, such as aspects of psychiatric nursing.

\section{THE CONTINUING FUNCTIONS OF THE UNIVERSITY}

\section{These include:}

- the periodic inspection of the facilities providing learning experiences for the different programmes. This is the same as discussed under the initial inspection

- the periodic review and revision of the rules and regulations

- the periodic review and evaluation of the course and the learning objectives

- the provision of advice and guidance on the extension of the library

- ensuring that the record system provides the necessary information for international, national and university purposes

- annually presenting a list of examiners to the university faculty and senate for approval

- acting as moderator for the examinations. This includes scrutinising and approving all the examination papers, approving the procedures adopted for the safe keeping of papers and sampling results, such as borderline marks

- reviewing the year's work and examination results

- providing in-service training for college tutors to enable them to keep abreast with the latest developments in nursing education and to improve their role as nurse educators

- assisting with the compilation and revision of programme manuals. These should contain copies of the agreement, SA Nursing Council regulations, university regulations, college regulations, programme objectives, curriculum outlines, and outlines of methods of evaluation, and so on
- ensuring that each lecturer has a manual with lesson objectives and lesson plans

- periodic review of the system of setting standards, teaching strategies and methods, system and quality of classroom and clinical teaching and quality of clinical care in areas where students are involved

- providing guidance and assistance with research on the education programme and acting as a link between the university, college, hospital and other instances in connection with research projects

- incorporating and supervising advanced diplomas in nursing science. These could have a common core and an area of specialisation.

\section{FINANCIAL ASPECTS}

The university requires that a financial commitment be made by the college for

- the cost of a staff point for each college associated with it. This needs periodic review as a college with a large number of students and/or offering more than one programme requires a larger amount of input from the university staff

- subsistence and travelling expenses for their staff members

* attending college council meetings two to three times per year * attending senate meetings two to three times per year

* attending curriculum design and evaluation meetings

These will be held annually, after the first course has been completed.

* conducting clinical practice assessments and evaluations at the end of each semester or year * attending graduation ceremonies

* carrying out specific functions on an ad hoc basis.

These costs can be contained by combining the dates for council and senate meetings and clinical evaluations as far as possible.

Continued on p. 25 